\title{
T. V. serial and Aggression
}

\author{
Mr. Pravin A Baviskar*, Dr. N. D. Mundada**,
}

\begin{abstract}
-
The present study was conducted to see the effect of violent t.v.serial on aggression level among the secondary school going students of Jalgaon city. Buss and Perrys Aggression Questionnaire was used to measure the aggression level of the adolescent. For this study a sample of 140 students of age range 14-16 years studying in $9^{\text {th }}$ and $10^{\text {th }}$ classes were selected from different school of Jalgaon city.
\end{abstract}

KEY WORD- Aggression, Violent T.V. Serial, Adolescent.

\section{INTRODUCTION-}

The effect of violent television serial and programmed on the human behavior, personality and aggression of the adolescent is the extremely sensitive and anxious subjects. Various types of destructive thoughts rise in the minds of the adolescent. It is due to the broad cast of television violent serial which teach immoral things, disastrous things, robbery, fighting with each -other, kidnapping cases etc. Through serial. The behavior becomes extremely attacking through such serials, obliviously it reflects in the psychological attitude. It also affects the aggression, there is no basic communication between parent child relationships and day by day it is being shattered. This question has disturbed me lot so \& have chosen the concerned topic for my research.

*Research Fellow, Dept of Psychology, S. S. M. M. College Pachora, Dist Jalgaon. (MS)

**Ph.D.Guide, Dept of Psychology, S. S. M. M. College, Pachora, Dist Jalgaon. (MS) 
During research on the effect of television on the adolescent the question such as, why do the children watch television? What is the reason behind watching television? Etc comes in my mind. If I try to answer the question above cited? May say that television is a medium of entertainment. Psychologically, television releaser the stress \& tension of daily routine, anxiety, tiresomeness, it also provides dreams completeness of unfinished wishes of human being. The adolescent can compare their personality with the hero \& heroines of the television serial. Some of the children watch television to get educated. It adds general knowledge and develops intellectual capacity. It is proved through research that as the preparation of the watching television grows, the question of choice arises and automatically the children turn to words their favorite program me.

\section{ADOLESCENT-}

Adolescence word come from Latin word adolescere meaning "To grow up" is a transitional stage of physical and psychological human development generally occurring between puberty and legal adulthood. It is a period of storm and stress. Adolescence has to adjust with their own changes in personality on one side and the changing socioeconomic environment on the other side some adolescent find it difficult to adjust normally with these change and experience some problem which are characteristics of this depending stage.

Adolescence period is most closely associated with the teenage years although it's physical, psychological and cultural expressions can begin earlier and end later.

\section{TELEVISION SERIAL}

\section{Definition-}

- Serial describes something that forms a series or is produced in multiple parts.

- A serial is something written or performed in parts.

\section{Aggression-}

- Any form of behavior that is intended to harm or injure some person, oneself, or an object.

- A feeling of hostility that arouses thoughts of attack. 
The International Journal of Indian Psychology: Volume: 01 | Issue: 03 | ISSN 2348-5396

Scholars have defined aggression from diver's perspective. However, there appears to be a consensus that aggression is a deliberate act intended to cause harm to another person.Bernstein,Penner,Clarke \& $\operatorname{Roy}(2006 ; 721)$ defined aggression as "an act that is intended to cause harm to another person" , Colman (2003) defined aggression as "a behavior whose primary or sole purpose or function is to injure physically or psychologically" Myers(2005) in his own submission defined aggression as physically or verbal behavior intended to hurt someone" Berhm,Kassin \& Fein(2005) "Aggression as behavior that is intended to harm another individual.

Based on the above definition aggression refers to any act that hurts, harms or destroyed which must be intended or deliberates.

\section{TYPES OF AGGRESSION}

\section{Physical aggression-}

Physical aggression is hostile from of aggression. Its aim is to cause body damage. It includes fighting, kicking, hair pulling, molesting, biting, pushing, shooting etc.

\section{Verbal aggression-}

Verbal aggression includes acts such as insulting with bad language, displaying anger, threatening and swearing to cause emotional and psychological pain.

\section{Hostility-}

Hostile aggression takes place when the aggressor primary intension is to harm the victim as a result of anger.

\section{Aggression -}

Aggression behavior is intended to harm another individual. Aggression refer to any act that hurts, harm or destroys which must be intended or deliberate.

One of the earliest and most well-known studies was conducted by Bandura in 1963. He had a group of children. They viewed a TV video of a model that kicked and punished an inflated 
plastic doll. After the viewing, the children were placed in a playroom with other children who had not seen the video. Those that saw the video displayed significantly more aggressive behaviour than those who didn't.

Present research study researcher comparing children who watched a violent short film with those who watched a non-violent one, the first group is consistently found to behave more aggressively towards each other (Bjorkqvist, 1985; Josephson, 1987)

Media violence is recognized as a potential contributor to the increase of antisocial attitudes in children and adolescents (Ledingham, Ledingham, \& Richardson, 1993).

Joy, Kimball, Zabrack ,1986; Williams, 1986, One of the most convincing studies compared the incidence of aggressive behaviour among children both before and two years after TV was introduced into the Canadian community where they resided. There was a significant increase in both physical and verbal aggression after two years of viewing TV.

Bushman \& Huesmann, 2001;Comstock, 1980; Geen, 1990; Geen \& Thomas, 1986; Huesmann, Moise, \& Podolski, 1997. The consistent finding from such randomized experiments is that youths who watch violent scenes subsequently display more aggressive behavior, aggressive thoughts, or aggressive emotions than those who do not.

\section{AIM OF THE STUDY -}

The aim of the present study is effect of violent T.V. Serial on aggression in adolescents of Jalgaon city.

\section{OBJECTIVE OF THE STUDY-}

This study is guided by the following objectives-

$>$ To find out the effect of violent t.v.serial on the aggression of male female adolescent.

$>$ To find out the effect of Non violent t. v. serial on the aggression of male female adolescent.

\section{HYPOTHESIS OF THE STUDY-}

Main hypothesis of the study are: 
There is significant difference in aggression between boys \& girls adolescents.

$>$ There is significant difference in aggression between the adolescents who watch violent $t$. v. serial and the adolescents who watch non violent $t$. v. serial.

\section{VARIABLE OF THE STUDY-}

Independent Variables - 1) Boys and Girls

2) Violent and Non Violent serial

\section{Dependent Variables - 1) Score of Aggression}

\section{METHODOLOGY -}

\section{Sample-}

The sample consists of 140 adolescents ( 70 boys and 70 girls) of various schools of jalgaon city. Their age range was 14 to 16 years. Sample was selected of simple random sampling.

\section{Experimental Design-}

The present study investigation is designed as $2 \times 2$ factorial design will be used. As well as to study an influence of TV serial and sex difference on aggression.

\section{Tools-}

For measuring the some independent variables and the dependent variable following standardized tests and scale were used.

\section{Aggression Questionnaire-(1992)}

This questionnaire was constructed and standardized by Perry and Buss. This questionnaire consists of 29 items and each item is provided with five alternatives. There is no time limit to this questionnaire. However the subject has to work as fast as he/she can. The reliability of the questionnaire reported by author was 0.82 . The validity of the questionnaire was 0.74

The aggression questionnaire consists of four factor, Physical aggression (PA), Verbal aggression (VA), Anger (A), and Hostility (H). The two questions with the asterisk are reverse scored. The total score for the aggression is the sum of the factor scores. 
The International Journal of Indian Psychology: Volume: 01 | Issue: 03 | ISSN 2348-5396

\section{RESULT AND DISCUSSION-}

In this part investigator has explained the result related to statistical analysis and hypothesis

Hypothesis - 1- There is significant difference in aggression between boys \& girls adolescents.

Table no- 1- Aggression and Gender

\begin{tabular}{|l|c|r|r|r|r|r|c|}
\hline $\begin{array}{l}\text { Gende } \\
\mathbf{r}\end{array}$ & Mean & \multicolumn{1}{c|}{$\mathbf{N}$} & $\begin{array}{c}\text { Std. } \\
\text { Deviation }\end{array}$ & $\begin{array}{c}\text { Std. Error } \\
\text { mean }\end{array}$ & $\begin{array}{c}\text { Mean } \\
\text { Difference }\end{array}$ & $\mathrm{t}$ & $\begin{array}{c}\text { Level of } \\
\text { significant }\end{array}$ \\
\hline Girls & 71.9571 & 70 & 11.53751 & 1.37900 & 9.31429 & & \\
\hline Boys & 81.2714 & 70 & 8.40449 & 1.00453 & 9.31429 & & \\
\hline
\end{tabular}

Above table no-1- is presenting the aggression among both male and female students. Investigator has selected 70 girls and 70 boys for study. The obtained t value is $\mathbf{5 . 4 5 9}$. So, we can say that there is significant difference of Aggression in boys and girls students and its hypothesis accepted.

Hypothesis -2 - There is significant difference in aggression between the adolescents who watch violent t. v. serial and the adolescents who watch non violent t. v. serial. 
Table no- 2- Aggression and T.V Serial

\begin{tabular}{|l|r|r|r|r|r|r|r|}
\hline $\begin{array}{l}\text { T.V. } \\
\text { Serial }\end{array}$ & Mean & $\mathbf{N}$ & Std. Deviation & $\begin{array}{c}\text { Std .Error } \\
\text { mean }\end{array}$ & $\begin{array}{c}\text { Mean } \\
\text { difference }\end{array}$ & $\begin{array}{l}\text { Level of } \\
\text { significa } \\
\text { nt }\end{array}$ \\
\hline Violent & $\begin{array}{r}77.014 \\
3\end{array}$ & 70 & 11.21269 & 1.34017 & 0.80000 & 0.426 & N.S \\
\hline $\begin{array}{l}\text { Non- } \\
\text { Violent }\end{array}$ & $\begin{array}{r}76.214 \\
3\end{array}$ & 70 & 11.03209 & 1.31859 & 0.80000 & & \\
\hline
\end{tabular}

Above table no-2- is presenting the aggression among both Violent serial and Non-violent serials. Investigator has selected 70 adolescent viewing violent TV serial and 70 adolescent viewing non-violent TV. serial for study. The obtained $\mathbf{t}$ value is $\mathbf{0 . 4 2 6}$. So, we can say that there is no significant difference of Aggression in adolescent who watch violent t. v. serial and the adolescents who watch non violent t. v. serial and its hypothesis rejected.

\section{Major finding of the study \& Conclusion-}

In this study, result has been discussed. Investigator has studied an influence of sex difference on aggression of the students. Result show that sex difference indicates significant influence on aggression but it indicates they did not significant difference on aggression in adolescent who watch violent t.v.serial and the adolescents who watch non violent t. v. serial. This study shows that boy's students are more aggressive than girl's students. There is no significant difference in aggression between the adolescent who watch both T.V. serials. 


\section{REFERENCES -}

1. Erickson, E. (1936) Childhood and society ( $2^{\text {nd }}$ ed) New York, Norton.

2. Hurlock, E.B.(1972) Child Development, New York, McGraw-Hill.

3. Anderson, C.A.\& Huesmann, L.R. (2003). Human aggression: A social-cognitive view. In M.A. Hogg \& J. Cooper (Eds.), Handbook of Social Psychology (pp. 296-323). London: Sage Publications.

4. Baron, R.T. (1998) Social Psychology, PHI Publications

5. Morgan .C.T. (2001) Introduction to Psychology, Tata McGraw Hill Publications

6. Ker linger .F.N. (2007) Foundation of Behavioral Research, $2^{\text {nd }}$ ed Delhi, Surjeet Publications

\section{Journal-}

1. Anderson, C.A.\& Dill, K.E. (2000).Video games and aggressive thoughts, feelings, and behavior in the laboratory and in life. Journal of Personality and Social Psychology, 78, 772-790.

2. Jonathan N.O.(2013) Physical and verbal aggression among adolescent secondary school students in rivers state of Nigeria. British Journal of Education 62-73 